\title{
Iron species and proteins distribution in unconventional food plants
}

\author{
Distribuição de espécies de ferro e proteínas em plantas \\ alimentícias não convencionais
}

\author{
Aline Pereira de Oliveira ${ }^{1}$, Juliana Naozuka ${ }^{1 *}$ \\ ${ }^{1}$ Universidade Federal de São Paulo (UNIFESP), Departamento de Química, Diadema/SP - Brasil \\ *Corresponding Author: Juliana Naozuka, Universidade Federal de São Paulo (UNIFESP), Departamento de \\ Química, R. Prof. Artur Riedel, 275, CEP: 09972-270, Diadema/SP - Brasil, e-mail: j.naozuka@unifesp.br
}

Cite as: Oliveira, A. P., \& Naozuka, J. (2021). Iron species and proteins distribution in unconventional food plants. Brazilian Journal of Food Technology, 24, e2020294. https://doi.org/10.1590/1981-6723.29420

\begin{abstract}
The sustainable food valorization is capable to stimulate the local products consumption with quality and nutritional security. In this scenario, Unconventional Food Plants (UFPs) deserve attention representing an alternative for rural communities and contributing to the local and regional economy. This work aimed to add nutritional information, once it evaluates total Fe concentration, Fe-species (water soluble, acid soluble, and inorganic), proteins, and Fe- proteins distribution in beldroega (Portulaca oleracea L.), guasca (Galinsoga parviflora Cav.), ora-pro-nóbis (Pereskia aculeata Mill.), piracá (Vernonia scorpioides (Lam.) Pers.), and trapoeraba (Commelina benghalensis L.). Considering the Fe total concentration, the studied UPFs can be excellent Fe sources, when compared to foods of plant origin widely consumed and cultivated, detaching the guasca leaves $\left(687 \pm 19 \mu \mathrm{g} \mathrm{g}^{-1}\right)$. However, the guasca leaves showed low concentration of Fe associated to macromolecules and Fe soluble species $\left(1.6 \pm 0.3 \mu \mathrm{g} \mathrm{g}^{-1}\right)$. These results may justify the low bioavailability of Fe species. On the other hand, beldroega leaves presented the highest concentration of inorganic Fe $\left(1.3 \pm 0.2 \mu \mathrm{g} \mathrm{g}^{-1}\right)$. In the UFPs, there is high glutelins concentration when compared to the other protein groups, meaning that UFPs can be low-cost alternative to supplementing protein intake. Finally, for majority UFPs, except guasca leaves, Fe is mainly associated to albumins, being a good source of bioavailable Fe species.
\end{abstract}

Keywords: Unconventional food plants; Speciation; Inorganic iron; Soluble iron; Proteins; Fe-proteins.

\section{Resumo}

A valorização de alimentos sustentáveis é capaz de estimular o consumo de produtos locais com qualidade e segurança nutricional. Nesse cenário, as plantas alimentícias não convencionais (PANCs) merecem destaque, representando uma alternativa para as comunidades rurais e contribuindo para a economia local e regional. Este trabalho visa agregar informações nutricionais através da avaliação da concentração total de $\mathrm{Fe}$, espécies de $\mathrm{Fe}$ (solúvel em água, solúvel em ácido e inorgânico) e proteínas, e da distribuição de Fe associado às proteínas em beldroega (Portulaca oleracea L.), guasca (Galinsoga parviflora), ora-pro-nóbis (Pereskia aculeata), piracá (Vernonia scorpioides) e trapoeraba (Commelina benghalensis L.). Considerando-se a concentração total de $\mathrm{Fe}$, as PANCs podem ser uma excelente fonte de $\mathrm{Fe}$, quando comparadas aos alimentos de origem vegetal comumente consumidos e cultivados, destacando-se as folhas de guasca $\left(687 \pm 19 \mathrm{\mu g} \mathrm{g}^{-1}\right)$. Entretanto, as folhas de guasca mostraram baixa concentração de Fe associado a macromoléculas (como proteínas) e espécies solúveis em água 
$\left(1,6 \pm 0,3 \mu \mathrm{g} \mathrm{g}^{-1}\right)$. Esses resultados podem justificar a baixa biodisponibilidade das espécies de Fe. Por outro lado, as folhas de beldroega apresentaram a maior concentração de Fe inorgânico $\left(1,3 \pm 0,2 \mu \mathrm{g} \mathrm{g}^{-1}\right)$. Nas PANCs, existe alta concentração de glutelínas, quando comparadas às concentrações dos outros grupos proteicos, significando que as PANCs podem ser uma alternativa de baixo custo para suplementar a ingestão de proteínas. Portanto, para a maioria das PANCs, exceto folhas de guasca, o Fe está principalmente associado às albuminas, sendo uma boa fonte de espécies de Fe biodisponível.

Palavras-chave: Plantas alimentícias não convencionais; Especiação; Ferro inorgânico; Ferro solúvel; Proteínas; Fe-proteínas.

\section{Introduction}

The current global agri-food system is supported by conventional agricultural matrix and also predominantly limited and industrialized food pattern, which contributes to the unfamiliarity and underutilization of native species with high economic and nutritional potential (Leal et al., 2018). The current rural system encourages the monocultures cultivation to meet the high demand for commonly consumed food, such as rice, beans, and wheat (Kelen et al., 2015; Leal et al., 2018). In addition, it is necessary to promote the consume the sustainable food that maximizes the consumption of local products with quality and nutritional security, respecting for biodiversity and adding value to farming, mainly family farming, and favoring a cultivation with low environmental impact.

It is estimated there are more than 10,000 plants potentially edible, highlighting Unconventional Food Plants (UFPs). The UFPs are exotic plants that, although edible, are not often used as food by most of the people, but may be part of the culture of some regions (Kinupp \& Lorenzi, 2014; Liberato et al., 2019; Paschoal \& Souza, 2015). These plants represent a subsistence alternative for rural communities and can contribute to the local and regional economy. The UFPs are often consumed as salad, braised, in forms of sweets, juices, or used for medicinal purposes (Luizza et al., 2013; Paschoal \& Souza, 2015; Brasil, 2010).

In general, UFPs are pest-resistant plants which are able to be grown in different climate conditions and can occupy areas where there is little sunshine, few fertile soils, or extreme humidity conditions that do not favor the cultivation of conventional food plants in addition to dispensing with the use of fertilizers and agricultural pesticides (Kinupp \& Lorenzi, 2014; Liberato et al., 2019; Paschoal \& Souza, 2015). The cultivation of UFPs assist in harnessing previously unproductive areas as well as this cultivation can bring a greater supply of healthy and low-cost food throughout the year (Luizza et al., 2013).

Studies on these edible plants show potential health effects, especially in relation to antioxidant protection and anti-inflammatory effects (Anusuya et al., 2012; Matu \& Van Staden, 2003; Pinto et al., 2012). The UFPs are often consumed as salad, braised, in forms of sweets, juices, or used for medicinal purposes (Brasil, 2010; Kinupp \& Lorenzi, 2014; Luizza et al., 2013). Among the various UFPs, some leaves can be detached, such as (1) "beldroega" (Portulaca oleracea L.) which is used as edible plant and traditional herbal medicine besides its leaves may help reduce the occurrence of cancer and heart disease as well as having anti-oxidation, anti-virus, anti-ulcerogenic, and anti-inflammatory properties (Chen et al., 2003; Xu et al., 2006); (2) "guasca" (Galinsoga parviflora Cav.) is used as a vegetable, seasoning, accompanying rice, roots, or white meat in which its leaves are good sources of protein, calcium $(\mathrm{Ca})$, and magnesium $(\mathrm{Mg})$, additionally can be applied for medicinal purposes with anti-inflammatory and antibacterial activities (Damalas, 2008; Odhav et al., 2007); (3) "ora-pro-nóbis" (Pereskia aculeata Mill.) is one of the most known UFPs which contain high levels of proteins, minerals, dietary fiber, vitamin $\mathrm{A}$, vitamin $\mathrm{C}$, and folic acid, consumed as salad or braised accompanying savory fillings and beans (Almeida \& Corrêa, 2012; Martinevski et al., 2013; Takeiti et al., 2009); (4) "trapoeraba" (Commelina benghalensis L.) is consumed as salad, braised, in forms of sweets, juices, or used for medicinal purposes and used as a popular medicine, due to antibacterial, sedative, and analgesic properties, i.e., this edible plant contains alkaloids, volatile oil, wax, vitamin $\mathrm{C}$ and high levels of vitamin $A$, and $\beta$-carotene (Anusuya et al., 2012). 
Studies about elemental chemical composition are paramount, since there are elements that play an important role in nutritional and medicinal values of plants. In this way, an example that should be highlighted is the iron $(\mathrm{Fe})$ concentration in spinach which contributes as the valuable sources of $\mathrm{Fe}$, being present in the daily diet mainly of the low-income socioeconomic classes (Yadav \& Sehgal, 2002). However, it is important to determine the $\mathrm{Fe}$ species present in food because in plants there is non-heme $\mathrm{Fe}$, which is absorbed in smaller amounts when compared to heme Fe species from sources of animal origin. The presence of oxalates, phosphates, phytates, and tannins in plants results in the formation of insoluble complexes with non-heme $\mathrm{Fe}$, limiting their absorption (Powell et al., 1999). Beans also have low concentration of bioavailable Fe species and are not able to supply nutritional needs in cases of deficiencies (Oliveira \& Naozuka, 2015).

Iron deficiency is one of the major public health problems in developing countries, such as Brazil, reaching levels up to $70 \%$ of the population in some regions (Obelar, 2008). Considering the worldwide profile, it is estimated that approximately $40 \%$ of the population presents Fe deficiency or low levels of hemoglobin establishing a risk situation that includes maternal-infant group (infants, preschoolers, school children, pregnant women, and nursing mothers) (Obelar, 2008).

The unknown potential of several UFPs requires further studies since these plants are promising from a medicinal and nutritional point of view and may be good alternative of Fe sources for human nutrition, especially in lower income socioeconomic classes in developing countries. Beside this, the UFPs cultivation can become an important tool in the production systems establishment in nutritious bases, valorization of family agriculture and polyculture production systems with low environmental impact rescuing the local biodiversity and the values of a more sustainable food. Therefore, this study aimed to determine the Fe total concentration and to evaluate the distribution of Fe-species (water soluble, acid soluble, inorganic, and Fe-proteins) and proteins in different UFPs as following: beldroega; guasca; ora-pro-nóbis; piracá; and trapoeraba.

\section{Materials and methods}

\subsection{Instrumentation}

For quantification of Fe total content, a Flame Atomic Absorption Spectrometer (F AAS) (Model AAS Vario 6, Analytik Jena AG, Germany) equipped with a deuterium lamp for background correction, was used. Acetylene flow of $70 \mathrm{~L} \mathrm{~h}^{-1}$, airflow of $430 \mathrm{~L} \mathrm{~h}^{-1}$ and an observation height of $6 \mathrm{~mm}$ were maintained.

After fractionation procedures, the Fe quantification was performed in a Graphite Furnace Atomic Absorption Spectrometer (GF AAS) (Model ZEEnit ${ }^{\circledR}$ 60, AnalytikjenaAG, Jena, Germany) equipped with a transversely heated graphite atomizer, a pyrolytically coated graphite tube and a transverse-Zeeman-effect background corrector. The spectrometer was operated using hollow cathode lamp, operating with wavelength, lamp current and slit-width equal to $248.3 \mathrm{~mm}, 4 \mathrm{~mA}$ and $0.8 \mathrm{~nm}$, respectively. All measurements were based on integrated absorbance values. Argon 99.998\% $\left(\mathrm{v} \mathrm{v}^{-1}\right)$ (Air Liquide Brasil, Brazil) was used as a protective and purge gas. The heating program for the graphite tube atomizer is shown in Table 1.

Table 1. Heating program for Fe determination by GF AAS.

\begin{tabular}{ccccc}
\hline Steps & $\begin{array}{c}\text { Temperature } \\
\left({ }^{\circ} \mathbf{C}\right)\end{array}$ & $\begin{array}{c}\text { Ramp } \\
\left({ }^{\circ} \mathbf{C ~ s}^{-1}\right)\end{array}$ & $\begin{array}{c}\text { Hold } \\
(\mathbf{s})\end{array}$ & $\begin{array}{c}\text { Argon flow } \\
(\mathbf{m L ~ m i n} \mathbf{~})\end{array}$ \\
\hline Drying & 100 & 10 & 15 & 1000 \\
\hline Drying & 130 & 10 & 20 & 1000 \\
\hline Pyrolysis & 1200 & 100 & 20 & 1000 \\
\hline Atomization & 2300 & 2300 & 5 & 0 \\
\hline Cleaning & 2500 & 1200 & 2 & 1000 \\
\hline
\end{tabular}


An Ultrospec 2100 Pro spectrophotometer (Biochrom LTD, Cambridge, UK), equipped with a xenon lamp and a wavelength range of $190-900 \mathrm{~nm}$, was used for protein determination at $595 \mathrm{~nm}$.

The samples and Standard Reference Material (SRM) digestion was carried out by a diluted oxidant mixture in a closed-vessel microwave system (Multiwave 3000, Anton Paar, Austria), equipped with sixteen fluoropolymer vessels and a ceramic vessel jacket.

In the proteins sequential extraction procedures and Fe chemical speciation, the homogenization of the culture medium was accomplished using an orbital shaker (model 0225M, Quimis, Brazil). A centrifuge (5415 R model, Eppendorf, Germany) was used to phase separation and protein precipitation.

For samples preliminary preparation, the leaves were dried using an oven (515 model, FANEM, SP, Brazil).

\subsection{Reagents and samples}

A mass of $500 \mathrm{~g}$ of different UFPs were purchased in the markets of the Sao Paulo city, in Brazil. The beldroega, ora-pro-nóbis, piracá, and trapoeraba species were purchased in the grocery, whereas guasca leaves in health foods stores.

All solutions were prepared from analytical reagent grade chemicals, using high-purity deionized water obtained from a Milli-Q water purification system (Millipore, USA) as the solvent. Analytical grade $65 \%$ $\left(\mathrm{v} \mathrm{v}^{-1}\right) \mathrm{HNO}_{3}$ distilled in a quartz sub-boiling still (Marconi, Brazil) and $30 \%\left(\mathrm{v} \mathrm{v}^{-1}\right) \mathrm{H}_{2} \mathrm{O}_{2}$ (Merck, Germany) were used to sample digestion.

Titrisol standard solution of $1000 \mathrm{mg} \mathrm{L}^{-1}$ of Fe (Merck, Germany) was used to prepare the reference analytical solutions in $0.14 \mathrm{~mol} \mathrm{~L}^{-1} \mathrm{HNO}_{3}$. The linear range used were $0.25-1.50 \mathrm{mg} \mathrm{L}^{-1}$ and $10-100 \mu \mathrm{g} \mathrm{L}^{-1}$ for Fe determination by F AAS and GF AAS, respectively.

The Fe total determination accuracy was evaluated by analysis of certified reference materials of peach leaves (SRM 1547) from the National Institute of Standards and Technology (NIST).

For sequential extraction procedure, acetone, chloroform, ethanol, methanol, sodium chloride $(\mathrm{NaCl})$, and sodium hydroxide $(\mathrm{NaOH})$ (Merck, Germany) were used. For evaluation of the protein precipitation procedure, it was used protein standard, prepared by dissolving $4.0 \mathrm{mg}$ of ovalbumin (BioAgency, Brazil) in $2.0 \mathrm{~mL}$ of deionized water, $100 \%\left(\mathrm{w} \mathrm{v}^{-1}\right)$ trichloroacetic acid (Sigma-Aldrich, USA), acetone (Merck, Germany), and $\mathrm{NaOH}$ (Merck, Germany).

The protein total concentration was obtained using Bradford's reagent (BioAgency, Brazil), which was diluted five times with deionized water before analysis, and ovalbumin stock solution (Merck, Germany).

Different precipitant reagents were prepared for Fe speciation: (1) $25 \mathrm{~g}$ of trichloroacetic acid (Merck, Germany) and $25 \mathrm{~mL}$ hydrochloride acid (Synth, Brazil); (2) $25 \mathrm{~g}$ of trichloroacetic acid (Merck, Germany), $25 \mathrm{~g}$ of hydroxylamine hydrochloride (Merck, Germany), and $25 \mathrm{~mL}$ of hydrochloride acid (Synth, Brazil). For both precipitant reagents, final volume of $250 \mathrm{~mL}$ was completed by deionized water.

\subsection{Sample preparation}

The raw UFPs leaves were washed with deionized water and dried in an oven at $60^{\circ} \mathrm{C}$ until constant mass. They were ground using a pestle and mortar (decontaminated) after freezing the samples in liquid nitrogen. Then, all results are presented in the dry sample mass.

For Fe determination, different leaves (beldroega, guasca, ora-pro-nóbis, piracá, and trapoeraba) or SRM were submitted to acid digestion in a closed-vessel microwave system. Sample masses ranging from 150 to $250 \mathrm{mg}$ were digested, using a dilute oxidant mixture $\left(2 \mathrm{~mL} \mathrm{HNO}_{3}+1 \mathrm{~mL} \mathrm{H}_{2} \mathrm{O}_{2}+3 \mathrm{~mL} \mathrm{H}_{2} \mathrm{O}\right)$ (Naozuka et al., 2011). The heating program consisted of three steps (temperature $/{ }^{\circ} \mathrm{C}, \mathrm{ramp} / \mathrm{min}$, hold $/ \mathrm{min}$ ): (1) $(140,5,1) ;(2)(180,4,5)$; and $(3)(220,4,10)$. The system was cooled through forced ventilation for 20 min. The digestion procedure was carried out in triplicates for each sample. After digestion, the samples and 
blank solutions were transferred to plastic flasks and their volumes were made up to $15 \mathrm{~mL}$ with deionized water.

Digested solutions were analyzed by F AAS and instrument calibration was performed using Fe analytical solutions ranging from 0.25 to $1.50 \mathrm{mg} \mathrm{L}^{-1}$ in $0.1 \% \mathrm{w} \mathrm{v}^{-1} \mathrm{HNO}_{3}$.

The SRM 1547 was submitted to acid digestion and analyzed by F AAS to check the accuracy. Besides this, addition and recovery test was also applied to verify the matrix interferences, adding $0.30 \mathrm{mg} \mathrm{L}^{-1}$ of Fe analytical solution to sample, after acid digestion in a microwave oven.

For proteins and Fe-proteins determination, the sequential extraction procedure has been described by Naozuka \& Oliveira (2007). A mass of $100 \mathrm{mg}$ of dried and grounded leaves was used to solid-liquid sequential extraction with different extractants: methanol/chloroform mixture $\left(1.5 \mathrm{~mL}, 1: 2 \mathrm{v} \mathrm{v}^{-1}\right)$; acetone $\left(1.5 \mathrm{~mL}, 75 \% \mathrm{v} \mathrm{v}^{-1}\right)$ (Do et al., 2014); deionized water $(1.0 \mathrm{~mL})$; $\mathrm{NaCl}\left(1.0 \mathrm{~mL}, 1 \mathrm{~mol} \mathrm{~L}^{-1}\right)$; ethanol $(1.0 \mathrm{~mL}$, $\left.70 \% \mathrm{v} \mathrm{v}^{-1}\right)$; and $\mathrm{NaOH}\left(1.0 \mathrm{~mL}, 1 \mathrm{~mol} \mathrm{~L}^{-1}\right)$. The methanol/chloroform was used to defat, the acetone was to remove phenols and the water, $\mathrm{NaCl}$, ethanol and $\mathrm{NaOH}$ were used to produce four protein fractions: albumin; globulin; prolamin; and glutelin, respectively. The extractions were carried out using an orbital shaker at $350 \mathrm{rpm}$ for $30 \mathrm{~min}$. The solid phase separation was carried out by centrifugation at $4000 \mathrm{rpm}$ for 10 minutes.

Subsequently, supernatants were submitted to precipitation procedure using the mixture trichloroacetic acid (TCA)/acetone (Fic et al., 2010; Koontz, 2014). Protein denaturation and concentration was performed by adding $100 \mu \mathrm{L}$ of TCA $\left(100 \% \mathrm{w} \mathrm{v}^{-1}\right)$ to $400 \mu \mathrm{L}$ of different supernatants (water, $\mathrm{NaCl}$, ethanol and $\mathrm{NaOH}$ ). The mixtures were shaken in orbital shaker at 350 $\mathrm{rpm}$ for $30 \mathrm{~min}$, followed by incubation for $1 \mathrm{~h}$ in an ice bath. After that, the samples were centrifuged at $12,000 \mathrm{rpm}$ for $10 \mathrm{~min}$ at $4{ }^{\circ} \mathrm{C}$. The precipitated proteins were washed once with ice-cold acetone $(500 \mu \mathrm{L})$ to remove any residual coloration and TCA, shaken in orbital shaker at 350 for $30 \mathrm{~min}$, and centrifuged at $12,000 \mathrm{rpm}$ for $10 \mathrm{~min}$ at $4{ }^{\circ} \mathrm{C}$. Finally, the proteins were resuspended in $0.5 \mathrm{~mL}$ of $\mathrm{NaOH}\left(0.1 \mathrm{~mol} \mathrm{~L}^{-1}\right)$. The protein precipitation efficiency was previously evaluated submitting $400 \mu \mathrm{L}$ of ovalbumin solution $\left(0.2 \mu \mathrm{g} \mathrm{L}^{-1}\right)$ to precipitation procedure.

Protein determination was performed by the Bradford method (Bradford, 1976), using $595 \mathrm{~nm}$ wavelength. Spectrophotometer calibration was performed using analytical reference solutions of 4, 6, 8, 10, 12, 16, and $20 \mu \mathrm{g}$ of ovalbumin in $1.0 \mathrm{~mL}$ of Bradford reagent.

Iron determination was carried out by GF AAS in the supernatants (water, $\mathrm{NaCl}$, ethanol, and $\mathrm{NaOH}$ ). Instrument calibration was performed using Fe analytical solutions ranging from 10 to $100 \mu \mathrm{g} \mathrm{L}^{-1}$ in $0.1 \% \mathrm{v}$ $\mathrm{v}^{-1} \mathrm{HNO}_{3}$. The chemical interferences were evaluated by addition and recovery test, adding an Fe solution $\left(20 \mu \mathrm{g} \mathrm{L}{ }^{-1}\right)$ to different supernatants.

For Fe speciation, the Fe soluble and inorganic species determination was done using an adapted procedure proposed by Oliveira et al. (2018). The different procedures were adopted and are shown in the Figure 1 .

For this, $7.0 \mathrm{~mL}$ of deionized water was added to $400 \mathrm{mg}$ of dried and ground leaves. This mixture was submitted to agitation for $5 \mathrm{~min}$ at room temperature and supernatant was separated by centrifugation at 4,000 rpm for $10 \mathrm{~min}$. The supernatants were analyzed by GF AAS, obtaining the Fe concentration in the aqueous extract (Fe soluble and $\mathrm{Fe}$ associated to macromolecules).

After that, it was added $2.5 \mathrm{~mL}$ of the precipitant reagent from 1 to $5 \mathrm{~mL}$ of aqueous extract, promoting the macromolecules precipitation (Koontz, 2014). The mixture was heated in a thermostatic bath at $95{ }^{\circ} \mathrm{C}$ for $10 \mathrm{~min}$, centrifuged at $4000 \mathrm{rpm}$ for $10 \mathrm{~min}$ and the supernatant was analyzed by GF AAS, obtaining the concentration of Fe soluble not associated to macromolecules (Quinteros et al., 2001). 


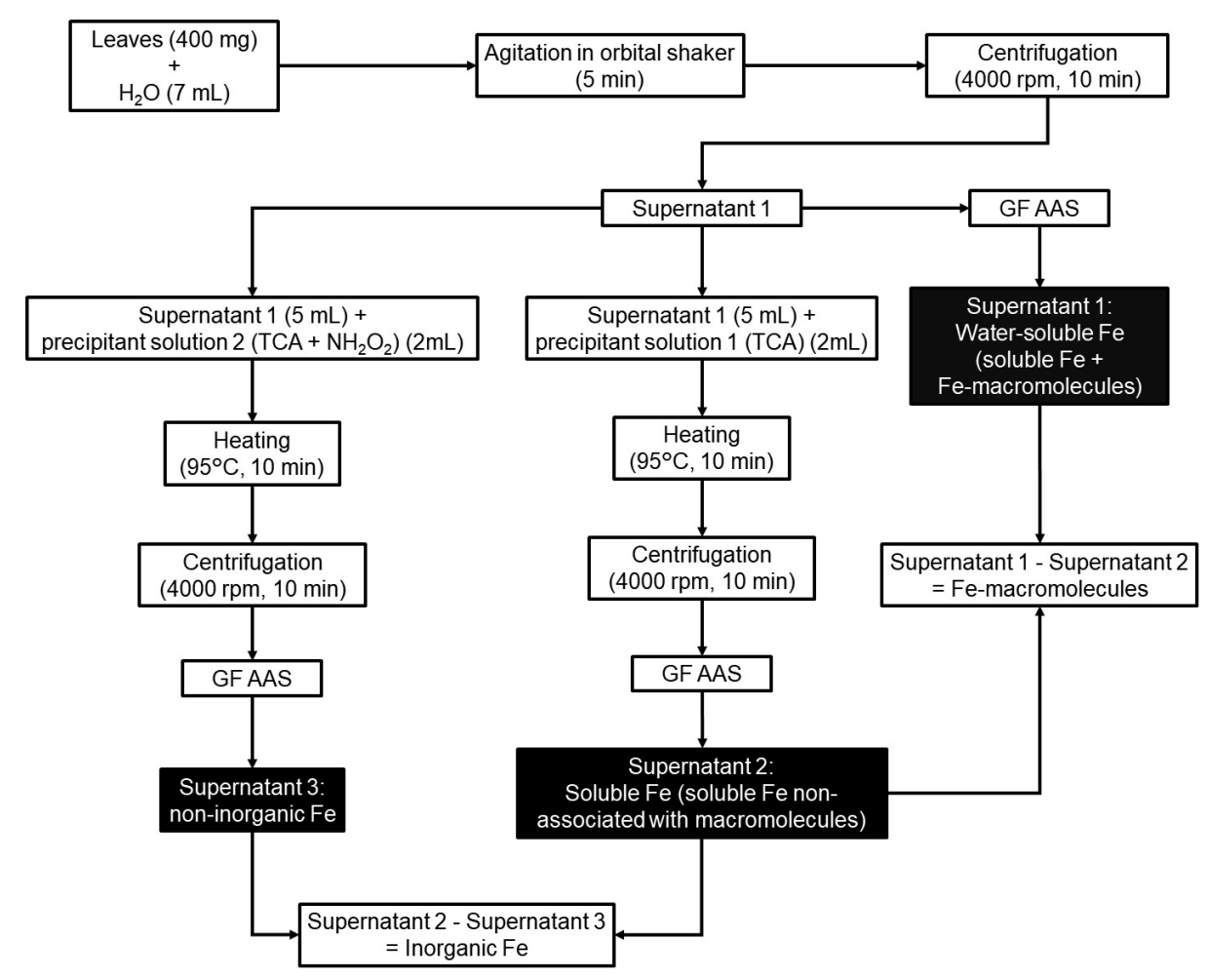

Figure 1. Flowchart of Fe speciation (Fe soluble, macromolecules and inorganic species).

Finally, $2.5 \mathrm{~mL}$ of the precipitant reagent 2 was added to $5 \mathrm{~mL}$ of the aqueous extract. The mixture was heated in a thermostatic bath at $95{ }^{\circ} \mathrm{C}$ for $10 \mathrm{~min}$, centrifuged at $4000 \mathrm{rpm}$ for $10 \mathrm{~min}$ and the supernatant was analyzed by GF AAS. This procedure was applied to precipitate macromolecules and promote the reduction of $\mathrm{Fe}(\mathrm{III})$ to $\mathrm{Fe}(\mathrm{II})$ (Quinteros et al., 2001).

The Fe determination in the supernatants was performed by GF AAS and the heating program according to Table 1 . The volume of $10 \mu \mathrm{L}$ of the samples or analytical solutions was injected into the graphite tube and no chemical modifier was used. The instrumental calibration was done with $\mathrm{Fe}$ analytical solutions ranging from 10 to $80 \mu \mathrm{g} \mathrm{L}^{-1}$ in $0.1 \%\left(\mathrm{v} \mathrm{v}^{-1}\right) \mathrm{HNO}_{3}$. To evaluate possible matrix interference in Fe determination, the addition and recovery test was performed. For this purpose, Fe analytical solution $\left(20 \mu \mathrm{g} \mathrm{L}^{-1}\right)$ was added in the presence of the precipitant reagents 1 and 2 , without and with addition of hydroxylamine, respectively.

\section{Results and discussion}

\subsection{Characteristics method of Fe determination}

The characteristics parameters for Fe determination by F AAS (total Fe) and GF AAS (Fe-proteins or Fe speciation), such as linear range, correlation coefficient $\left(\mathrm{R}^{2}\right)$, Limit of Detection (LOD) and Limit of Quantification (LOQ) are shown in Table 2. LOD was calculated using the standard deviation of 10 measurements of the analytical blank sample (LOD $=3 \times \sigma_{\text {blank, }}$, where $\sigma$ is the standard deviation), and $\mathrm{LOQ}=3 \times \mathrm{LOD}$. For total $\mathrm{Fe}$, values were obtained in $\mu \mathrm{g} \mathrm{g}^{-1}$ considering a sample mass of $150 \mathrm{mg}$ and a final volume of $15 \mathrm{~mL}$. For Fe-proteins, values were obtained in $\mathrm{ng} \mathrm{g}^{-1}$, considering a sample mass of 100 $\mathrm{mg}$ and a final volume of $1 \mathrm{~mL}$. For Fe species, values were obtained in $\mathrm{ng} \mathrm{g}^{-1}$ considering a sample mass of $400 \mathrm{mg}$ and a final volume of $10 \mathrm{~mL}$. 
Table 2. Characteristics method for Fe determination by F AAS and GF AAS.

\begin{tabular}{|c|c|c|c|c|c|c|}
\hline & Analytical Blank & Linear range & $\mathbf{R}^{2}$ & LOD & LOQ & Recovery (\%) \\
\hline F AAS ${ }^{*}$ & $\mathrm{HNO}_{3}$ & $0.25-1.50$ & 0.9945 & 8.5 & 28.1 & 111 \\
\hline \multirow{6}{*}{ GF AAS ${ }^{* *}$} & Water & \multirow{4}{*}{$10-100$} & \multirow{4}{*}{0.9984} & 20 & 61 & 113 \\
\hline & $\mathrm{NaCl}$ & & & 37 & 111 & 96 \\
\hline & Ethanol & & & 12 & 36 & 87 \\
\hline & $\mathrm{NaOH}$ & & & 38 & 114 & 117 \\
\hline & Precipitant reagent 1 & \multirow{2}{*}{$10-100$} & \multirow{2}{*}{0.9984} & 20 & 60 & 108 \\
\hline & Precipitant reagent 2 & & & 60 & 190 & 103 \\
\hline
\end{tabular}

F AAS: Flame Atomic Absorption Spectrometer. GF AAS: Graphite Furnace Atomic Absorption Spectrometer. LOD: Limit of Detection. LOQ: Limit of Quantification. *Linear range $\left(\mathrm{mg} \mathrm{L}^{-1}\right)$. LOD and LOQ $\left(\mu \mathrm{g} \mathrm{g}^{-1}\right) . * *$ Linear range $\left(\mu \mathrm{g} \mathrm{L}^{-1}\right)$; LOD and LOQ $\left(\mathrm{ng} \mathrm{g}^{-1}\right)$.

Recovery percentages, Table 2, ranged from 87 (ethanol) to 117 (NaOH)\%. According to NBR ISO/IEC 17025, the recovery tolerance ranges from $80 \%$ to $120 \%$ (Burin et al., 2008), evidencing the matrix interferences absence in the Fe determination by GF AAS and F AAS. Additionally, the results quality obtained by F AAS was assessed by SRM 1547 analysis, which was subjected to the same experimental procedures adopted for the acid digestion of the samples. The results obtained showed that the analytical method is selective and accurate. The certified and experimental values were compared by Student's $t$ test at $95 \%$ confidence limit and it was found that there was no significant difference, since the certified value is $219.8 \mu \mathrm{g} \mathrm{g}^{-1}$ and experimental Fe concentration was $217 \pm 17 \mu \mathrm{g} \mathrm{g}^{-1}$.

\subsection{Total Fe and Fe species (soluble and inorganic) in UFPs}

The Fe total and species concentrations in UFPs (beldroega, guasca, ora-pro-nóbis, piracá, and trapoeraba) are shown in Table 3. The different Fe species were quantified in supernatants obtained after extraction with water, precipitant reagent 1 and precipitant reagent 2. After addition of the precipitant reagents 1 and 2, it was possible to quantify acid soluble non-macromolecular and inorganic Fe, respectively. The TCA addition could promote the proteins and peptides precipitation and hydroxylamine absence, then, it was possible to obtain the concentration of acid soluble Fe non-associated with macromolecules (Koontz, 2014; Oliveira \& Naozuka, 2015). The TCA and hydroxylamine addition allowed the total inorganic Fe quantification, since $\mathrm{Fe}(\mathrm{III})$ was reduced to $\mathrm{Fe}(\mathrm{II})$ ions and $\mathrm{Fe}$ reduced species interactions with macromolecules, such as antinutritional components, forming solid compounds that suffer precipitation (Oliveira \& Naozuka, 2015). Finally, it was possible to quantify $\mathrm{Fe}$ inorganic total, subtracting the $\mathrm{Fe}$ concentrations found in the supernatants obtained after addition of precipitant reagent 1 from precipitant reagent 2 .

Table 3. Fe concentrations in supernatants and digested samples.

\begin{tabular}{cccccc}
\hline & \multicolumn{4}{c}{ Fe concentration $\left(\mu \mathbf{\mu g ~ g}^{-1}\right) \pm$ Standard Deviation $(\mathbf{n}=\mathbf{3})$} \\
\cline { 2 - 5 } & Beldroega & Guasca & Ora-pro-nóbis & Piracá & Trapoeraba \\
\hline Total & $46 \pm 2$ & $687 \pm 19$ & $123 \pm 6$ & $283 \pm 6$ & $138 \pm 2$ \\
\hline Aqueous extract & $2.5 \pm 0.1^{\mathrm{a}}$ & $1.6 \pm 0.3^{\mathrm{a}}$ & $5.7 \pm 0.2^{\mathrm{a}}$ & $5.7 \pm 0.2^{\mathrm{a}}$ & $3.8 \pm 0.1^{\mathrm{a}}$ \\
\hline $\begin{array}{c}\text { Precipitant reagent 1 (without } \\
\text { hydroxylamine, } \mathrm{pH}<1)\end{array}$ & $2.4 \pm 0.2^{\mathrm{a}}$ & $1.0 \pm 0.1^{\mathrm{b}}$ & $4.6 \pm 0.2^{\mathrm{b}}$ & $4.6 \pm 0.2^{\mathrm{b}}$ & $3.3 \pm 0.2^{\mathrm{b}}$ \\
\hline $\begin{array}{c}\text { Precipitant reagent 2 (with } \\
\text { hydroxylamine, } \mathrm{pH}=5,5)\end{array}$ & $1.1 \pm 0.1^{\mathrm{b}}$ & $0.55 \pm 0.01^{\mathrm{c}}$ & $5.0 \pm 0.2^{\mathrm{b}}$ & $5.0 \pm 0.2^{\mathrm{b}}$ & $2.9 \pm 0.3^{\mathrm{b}}$ \\
\hline Inorganic $\mathrm{Fe}^{*}$ & $1.3 \pm 0.2$ & $0.45 \pm 0.10$ & $\mathrm{ND}^{* *}$ & $\mathrm{ND}^{* *}$ & $\mathrm{ND}^{* *}$ \\
\hline
\end{tabular}

*Subtraction of the Fe concentration in the extract with hydroxylamine of the extract without hydroxylamine. **ND: Not determined.

${ }^{a-c}$ Different superscripts within the same plant species indicate significant differences between Fe concentration in the supernatants $(p<0.05)$.

It was verified that guasca leaves is an excellent Fe source and an alternative for the anemia treatment caused by Fe deficiency, since it showed the highest Fe total concentration $\left(687 \pm 19 \mu \mathrm{g} \mathrm{g}^{-1}\right)$. The results indicated that guasca leaves were characterized as higher Fe bioaccumulator than others studied plants. Considering the Dietary Reference Intake (DRI) of Fe for an adult male (31 to 50 years old) equal to $18 \mathrm{mg}$ 
(Dolan \& Capar, 2002), the guasca consumption of $26.2 \mathrm{~g}$ of leaves would reach the Fe daily recommendation. For others UFPs, the same mass $(26.2 \mathrm{~g})$ would contribute between 6.7 (beldroega) and 41.2 (piracá) $\%$ of the Fe DRI.

Studies published previously by our research group indicated that the black bean showed the highest $\mathrm{Fe}$ total concentration $\left(94 \pm 3 \mathrm{ug} \mathrm{g}^{-1}\right)$ (Oliveira \& Naozuka, 2015). However, the guasca and piracá leaves have $\mathrm{Fe}$ concentrations of seven and three times, respectively, higher than black beans, detaching the UFPs potential to supply Fe deficiencies. Besides that, it is important to point out that comparisons between obtained results and other literature works is difficult, since that genetic and physiology differences, soil characteristics, different water source and external factors (eg. fertilizers, insecticides, and pesticides) can vary the essential elemental concentrations in the UPFs (Harnly et al., 2009). An example of this is associated with the results obtained by Oliveira et al. (2013), where a high Fe concentration was found in the bedroega when compared to ora-pro-nóbis, being the opposite to the observed in this work (Fe concentrations in bedroega $\left(46 \pm 2 \mu \mathrm{g} \mathrm{g}^{-1}\right)$ and ora-pro-nóbis $\left(123 \pm 6 \mu \mathrm{g} \mathrm{g}^{-1}\right)$.

It is important to know the Fe species concentration, which are potentially absorbed by the human organism, since the total $\mathrm{Fe}$ concentration cannot provide essentiality and toxicity information (Naozuka, 2018). Non-heme Fe species can be found in vegetable foods, such as Fe(II) and/or Fe(III). However, less than $5 \%$ of these $\mathrm{Fe}$ species are absorbed by human organism, being that $\mathrm{Fe}(\mathrm{II})$ is more available than $\mathrm{Fe}(\mathrm{III})$ (Quinteros et al., 2001). It is possible that in the fraction containing Fe soluble and Fe associated to macromolecules (aqueous extract) there are Fe species available, mainly $\mathrm{Fe}$ associated to albumins. In relation to $\mathrm{Fe}$ total concentration, the Fe concentration in the aqueous extract ranged from $0.2 \%$ (guasca) to $5.4 \%$ (beldroega). It is interesting to observe that, even though guasca act as a good Fe source, this leave had the lowest concentration of $\mathrm{Fe}$ species potentially available $\left(1.6 \pm 0.3 \mu \mathrm{g} \mathrm{g}^{-1}\right)$.

The decrease in Fe concentration in the supernatant after addition of precipitant reagent 1, ranged from 0 (beldroega) to 20\% (ora-pro-nóbis and piracá) when compared to the Fe concentration in the aqueous extract. It was possible to infer that in studied UFPs there is a small percentage of Fe soluble associated to macromolecules.

Comparing the Fe concentrations after the addition of the precipitant reagents 1 and 2, it was verified that the Fe concentration decreased only for the beldroega (54\%) and guasca (45\%) leaves. Although beldroega leaves had the lowest total $\mathrm{Fe}$ concentration, it was the plant species that presented the highest concentration of inorganic Fe $\left(1.3 \pm 0.2 \mu \mathrm{g} \mathrm{g}^{-1}\right)$. Lastly, although ora-pro-nóbis, piracá, and trapoeraba leaves presented the highest concentration of water-soluble Fe species, inorganic Fe species were not determined, indicating that water-soluble $\mathrm{Fe}$ species in these leaves are associated to compounds of low molecular weight and soluble fibers, which are not precipitated by the action of trichloroacetic acid and hydroxylamine.

\subsection{Proteins and Fe-proteins distribution in UFPs}

The sequential extraction using the extractants water, $\mathrm{NaCl}$, ethanol, and $\mathrm{NaOH}$ allows the separation of albumin, globulin, prolamin and glutelins, respectively (Fabian \& Ju, 2011). The protein quantification was done by Bradford method (Bradford, 1976) obtaining analytical signals in wavelength in the visible region $(595 \mathrm{~nm})$. Therefore, it was necessary the protein isolation/purification by precipitation, using a mixture of TCA and acetone, since an intense green color was observed in the supernatants obtained after sequential extraction, due to chlorophyll presence. This procedure was evaluated using standard solution of ovoalbumin in which $100 \%$ of recovery was achieved. Additionally, the LOD and LOQ were also obtained, considering $100 \mathrm{mg}$ sample mass and a final volume of $0.5 \mathrm{~mL}$, corresponding to 66 and $198 \mu \mathrm{g} \mathrm{g}^{-1}$, respectively.

The concentrations of albumin, globulin, prolamin, glutelin and Fe associated to these protein types are presented in Table 4. The glutelin group is in higher concentrations for most of the studied leaves, ranging from $0.20 \pm 0.02$ (guasca) to $3.1 \pm 0.3$ (piracá) $\mathrm{mg} \mathrm{g}^{-1}$. On the other hand, prolamin group showed the lowest concentrations in all leaves, all of them below the LOQ. The evaluation of the amino acids bioavailability in 
the determined protein group is an important role for proteins nutritional value in plants. Studies by Chan \& Phillips (1994) in plant origin foods indicated that the prolamins and glutelins have the highest concentrations of methionine, which is a sulfur-rich amino acid. Therefore, higher glutelins concentration than the other protein groups in the evaluated UFPs may indicate a high nutritional value of these foods. In addition, considering the protein concentration sum of the different groups, piracá leaves had the highest proteins concentration $\left(5.5 \pm 0.3 \mathrm{mg} \mathrm{g}^{-1}\right)$, being similar to those found in bean sprouts published in previous studies of our research group (Oliveira et al., 2013, 2017, 2018). In summary, UFPs may be a low-cost alternative to supplementing protein intake, mainly in developing countries with protein malnutrition.

Metalloproteins, such as Fe-proteins, in foods are chemical species potentially absorbed by human body. The Fe metalloproteins formation can be explain due to presence of amino acids, as methionine, cysteine, glutamic acid, arginine, aspartic acid, and lysine, that are rich in sulfur and charged groups, which have high affinity toward transition metal ions and non-metals (Garcia et al., 2006). In general, it was found that $\mathrm{Fe}$ is mainly associated to proteins from the albumins, Table 4, ranging from $1.1 \pm 0.1$ (guasca) to $13.7 \pm 0.3$ (piracá) $\mu \mathrm{g} \mathrm{g}^{-1}$, and less associated to prolamins group proteins, ranging from $0.26 \pm 0.01$ (ora-pro-nóbis) to $0.96 \pm 0.04$ (trapoeraba) $\mu \mathrm{g} \mathrm{g}^{-1}$. Only the guasca leaves showed that Fe was mainly associated to prolamins. Comparing the sum of the concentration of Fe associated to proteins with Fe total concentration, it was verified that it ranged from 1.2 (guasca) to $10.5 \%$ (ora-pro-nóbis). Although ora-pro-nóbis leaves presented one of the lowest Fe total concentrations, these leaves had the highest Fe-proteins concentration.

Table 4. Protein and Fe-protein concentrations in different UFPs leaves.

\begin{tabular}{ccccc}
\hline & \multicolumn{3}{c}{ Protein concentration $\left(\mathbf{m g ~ g}^{-\mathbf{1}}\right) \pm$ Standard Deviation $(\mathbf{n}=\mathbf{3})$} \\
\cline { 2 - 5 } & Albumin & Globulin & Prolamin & Glutelin \\
\hline Beldroega & $0.29 \pm 0.02$ & $<$ LOQ & $<$ LOQ & $1.2 \pm 0.1$ \\
\hline Guasca & $<$ LOQ & $<$ LOQ & $<$ LOQ & $0.20 \pm 0.02$ \\
\hline Ora-pro-nóbis & $2.0 \pm 0.1$ & $0.8 \pm 0.1$ & $<$ LOQ & $0.75 \pm 0.04$ \\
\hline Piracá & $1.8 \pm 0.1$ & $0.62 \pm 0.02$ & $<$ LOQ & $3.1 \pm 0.3$ \\
\hline Trapoeraba & $<$ LOQ & $<$ LOQ & $<$ LOQ & $0.65 \pm 0.01$ \\
\hline Beldroega & & Fe concentration $\left(\boldsymbol{\mu g} \mathbf{g}^{-1}\right) \pm$ Standard Deviation $(\mathbf{n}=\mathbf{3})$ & \\
\hline Guasca & $1.2 \pm 0.2$ & $0.54 \pm 0.01$ & $0.42 \pm 0.04$ & $0.9 \pm 0.1$ \\
\hline Ora-pro-nóbis & $1.1 \pm 0.1$ & $0.24 \pm 0.01$ & $4.4 \pm 0.3$ & $2.3 \pm 0.1$ \\
\hline Piracá & $8.9 \pm 0.3$ & $2.3 \pm 0.1$ & $0.26 \pm 0.01$ & $1.5 \pm 0.2$ \\
\hline Trapoeraba & $13.7 \pm 0.3$ & $1.1 \pm 0.1$ & $0.61 \pm 0.01$ & $6.1 \pm 0.4$ \\
\hline
\end{tabular}

\section{Conclusions}

Considering the Fe total concentration, the studied UPFs (beldroega, guasca, ora-pro-nóbis, piracá, and trapoeraba) can be excellent Fe sources, when compared to foods of plant origin widely consumed and cultivated. It is important to point out that Fe concentrations in the UPFs may change due to genetic and physiology differences, soil characteristics, different water source and external factors (eg. fertilizers, insecticides, and pesticides). The guasca leaves presented high Fe concentration, but low concentration of soluble Fe associated to macromolecules and inorganic Fe species. These results may justify the low bioavailability of Fe species.

In the UFPs, there is high glutelins concentration compared to the other protein groups, meaning that UFPs can be low-cost alternative to supplementing protein intake. Finally, for majority UFPs, except guasca leaves, $\mathrm{Fe}$ is mainly associated to albumins, being a good source of bioavailable Fe specie. 


\section{Acknowledgements}

Aline Pereira de Oliveira [grant number 2017/05009-7] and Juliana Naozuka [grant number 2018/063329] thank the Fundação de Amparo à Pesquisa do Estado de São Paulo/FAPESP for providing the fellowship and financial support, respectively. The authors also thank the Coordenação de Aperfeiçoamento de Pessoal de Nivel Superior/CAPES for financial support provided by the Graduate Program in Chemistry Sustainability Science and Technology.

\section{References}

Almeida, M. E. F. D., \& Corrêa, A. D. (2012). Utilização de cactáceas do gênero Pereskia na alimentação humana em um município de Minas Gerais. Ciência Rural, 42(4), 751-756. http://dx.doi.org/10.1590/S0103-84782012000400029

Anusuya, N., Gomathi, R., Manian, S., Sivaram, V., \& Menon, A. (2012). Evaluation of Basella rubra L., Rumex nepalensis Spreng and Commelina benghalensis L. for antioxidant activity. International Journal of Pharmacy and Pharmaceutical Sciences, 4, 714-720.

Bradford, M. M. (1976). A rapid and sensitive method for the quantitation of microgram quantities of protein utilizing the principle of protein-dye binding. Analytical Biochemistry, 72(1-2), 248-254. PMid:942051. http://dx.doi.org/10.1016/0003-2697(76)905273

Brasil. Ministério da Agricultura, Pecuária e Abastecimento. (2010). Hortaliças não-convencionais (tradicionais). Brasília. Retrieved in 2020, April 13 , from https://www.abcsem.com.br/docs/cartilha_hortalicas.pdf

Burin, R., Burin, V. M., Taha, P., \& Bordignon-Luiz, M. T. (2008). Validation of an analytical methodology for calcium determination in meat products. Food Science and Technology, 28(4), 973-978. http://dx.doi.org/10.1590/S010120612008000400033

Chan, C. W., \& Phillips, R. D. (1994). Amino acid composition and subunit constitution of protein fractions from cowpea (Vigna unguiculata L. Walp) seeds. Journal of Agricultural and Food Chemistry, 42(9), 1857-1860. http://dx.doi.org/10.1021/jf00045a005

Chen, J., Shi, Y. P., \& Liu, J. Y. (2003). Determination of noradrenaline and dopamine in Chinese herbal extracts from Portulaca oleracea L. by high-performance liquid chromatography. Journal of Chromatography A, 1003(1-2), 127-132. PMid:12899302. http://dx.doi.org/10.1016/S0021-9673(03)00786-6

Damalas, C. A. (2008). Distribution, biology, and agricultural importance of Galinsoga parviflora (Asteraceae). Weed Biology and Management, 8(3), 147-153. http://dx.doi.org/10.1111/j.1445-6664.2008.00290.x

Do, Q. D., Angkawijaya, A. E., Tran-Nguyen, P. L., Huynh, L. H., Soetaredjo, F. E., Ismadji, S., \& Ju, Y. H. (2014). Effect of extraction solvent on total phenol content, total flavonoid content, and antioxidant activity of Limnophila aromatica. Journal of Food and Drug Analysis, 22(3), 296-302. PMid:28911418.

Dolan, S. P., \& Capar, S. G. (2002). Multi-element analysis of food by microwave digestion and inductively coupled plasmaatomic emission spectrometry. Journal of Food Composition and Analysis, 15(5), 593-615. http://dx.doi.org/10.1016/S08891575(02)91064-1

Fabian, C., \& Ju, Y. H. (2011). A review on rice bran protein: Its properties and extraction methods. Critical Reviews in Food Science and Nutrition, 51(9), 816-827. PMid:21888532. http://dx.doi.org/10.1080/10408398.2010.482678

Fic, E., Kedracka-Krok, S., Jankowska, U., Pirog, A., \& Dziedzicka-Wasylewska, M. (2010). Comparison of protein precipitation methods for various rat brain structures prior to proteomic analysis. Electrophoresis, 31(21), 3573-3579. PMid:20967768. http://dx.doi.org/10.1002/elps.201000197

Garcia, J. S., Magalhães, C. S., \& Arruda, M. A. Z. (2006). Trends in metal-binding and metalloprotein analysis. Talanta, 69(1), 1-15. PMid:18970524. http://dx.doi.org/10.1016/j.talanta.2005.08.041

Harnly, J. M., Pastor-Corrales, M. A., \& Luthria, D. L. (2009). Variance in the chemical composition of dry beans determined from UV spectral fingerprints. Journal of Agricultural and Food Chemistry, 57(19), 8705-8710. PMid:19731933. http://dx.doi.org/10.1021/jf900852y

Kelen, M. E. B., Nouhuys, I. S. V., Kehl, L. C., Brack, P., \& Silva, D. D. (2015). Plantas alimentícias não convencionais (PANCs): Hortaliças espontâneas e nativas (1. ed.). Porto Alegre: UFRGS.

Kinupp, V. F., \& Lorenzi, H. J. (2014). Plantas Alimentícias Não Convencionais (PANC) no Brasil: Guia de identificação, aspectos nutricionais e receitas ilustradas (1. ed.). Nova Odessa: Instituto Plantarum de Estudos.

Koontz, L. (2014). TCA precipitation. Methods in Enzymology, 541, 3-10. PMid:24674058. http://dx.doi.org/10.1016/B978-0-12420119-4.00001-X

Leal, M. L., Alves, R. P., \& Hanazaki, N. (2018). Knowledge, use, and disuse of unconventional food plants. Journal of Ethnobiology and Ethnomedicine, 14(1), 6. PMid:29343263. http://dx.doi.org/10.1186/s13002-018-0209-8

Liberato, P. D. S., Travassos, D. V., \& Silva, G. M. B. (2019). PANCs-plantas alimentícias não convencionais e seus benefícios nutricionais. Environmental Smoke, 2(2), 102-111. http://dx.doi.org/10.32435/envsmoke.201922102-111

Luizza, M. W., Young, H., Kuroiwa, C., Evangelista, P., Worede, A., Bussmann, R. W., Weimer, A., \& Young, N. (2013).

Integrative spatial modeling: Utilizing local ecological knowledge and geospatial applications to model ecosystem services and 
assess their vulnerability. Retrieved in 2021 , February 17 , from https://collaborativeconservation.org/media/sites/142/2018/01/isa_2013paper_LUIZZA.pdf

Martinevski, C. S., Oliveira, V. R., Rios, A. D. O., Flores, S. H., \& Venzke, J. G. (2013). Utilization of bertalha (Anredera cordifolia (Ten.) Steenis) and ora pro nobis (Pereskia aculeata Mill.) in preparing breads. Alimentos e Nutrição, 24(3), 1-6.

Matu, E. N., \& Van Staden, J. (2003). Antibacterial and anti-inflammatory activities of some plants used for medicinal purposes in Kenya. Journal of Ethnopharmacology, 87(1), 35-41. PMid:12787952. http://dx.doi.org/10.1016/S0378-8741(03)00107-7

Naozuka, J. (2018). Elemental enrichment of foods: Essentiality and toxicity. Nutrition \& Food Science International Journal, 4(3), 80-84. http://dx.doi.org/10.19080/NFSIJ.2018.04.555640

Naozuka, J., \& Oliveira, P. V. (2007). Cu, Fe, Mn and Zn distribution in protein fractions of Brazil-nut, cupuassu seed and coconut pulp by solid-liquid extraction and electrothermal atomic absorption spectrometry. Journal of the Brazilian Chemical Society, 18(8), 1547-1553. http://dx.doi.org/10.1590/S0103-50532007000800015

Naozuka, J., Vieira, E. C., Nascimento, A. N., \& Oliveira, P. V. (2011). Elemental analysis of nuts and seeds by axially viewed ICP OES. Food Chemistry, 124(4), 1667-1672. http://dx.doi.org/10.1016/j.foodchem.2010.07.051

Obelar, M. D. S. (2008). Anemia carencial na infância: Um importante problema de saúde pública. Revista Paulista de Pediatria, 26(1), 4-5. http://dx.doi.org/10.1590/S0103-05822008000100001

Odhav, B., Beekrum, S., Akula, U. S., \& Baijnath, H. (2007). Preliminary assessment of nutritional value of traditional leafy vegetables in KwaZulu-Natal, South Africa. Journal of Food Composition and Analysis, 20(5), 430-435. http://dx.doi.org/10.1016/j.jfca.2006.04.015

Oliveira, A. P., \& Naozuka, J. (2015). Chemical speciation of iron in different varieties of beans (Phaseolus vulgaris L.): Cooking effects. Journal of the Brazilian Chemical Society, 26(10), 2144-2149.

Oliveira, A. P., Nomura, C. S., \& Naozuka, J. (2017). Evaluation of selenium enrichment of adzuki bean (Vigna angularis) sprouts: Translocation, bioaccessibility and Se-protein speciation. Microchemical Journal, 134, 19-26. http://dx.doi.org/10.1016/j.microc.2017.05.004

Oliveira, A. P., Nomura, C. S., Silva, S. G., \& Naozuka, J. (2018). Iron and selenium speciation in enriched adzuki bean sprouts after fractionation procedures by graphite furnace atomic absorption spectrometry. Journal of Analytical \& Pharmaceutical Research, 7(2), 104-112.

Oliveira, D. D. C. D. S., Wobeto, C., Zanuzo, M. R., \& Severgnini, C. (2013). Composição mineral e teor de ácido ascórbico nas folhas de quatro espécies olerícolas não-convencionais. Horticultura Brasileira, 31(3), 472-475. http://dx.doi.org/10.1590/S010205362013000300021

Paschoal, V., \& Souza, N. (2015). Plantas Alimentícias Não Convencionais (PANC). In D. F. S. Chaves (Ed.), Nutrição clínica funcional: Compostos bioativos dos alimentos (pp. 302-323). São Paulo: VP Editora.

Pinto, N. D. C. C., Santos, R., Machado, D. C., Florêncio, J. R., Fagundes, E. M. Z., Antinarelli, L. M. R., Coimbra, E. S., Ribeiro, A., \& Scio, E. (2012). Cytotoxic and antioxidant activity of Pereskia aculeata Miller. Pharmacologyonline, 3, 63-69.

Powell, J. J., Jugdaohsingh, R., \& Thompson, R. P. H. (1999). The regulation of mineral absorption in the gastrointestinal tract. The Proceedings of the Nutrition Society, 58(1), 147-153. PMid:10343352. http://dx.doi.org/10.1079/PNS19990020

Quinteros, A., Farre, R., \& Lagarda, M. J. (2001). Optimization of iron speciation (soluble, ferrous and ferric) in beans, chickpeas and lentils. Food Chemistry, 75(3), 365-370. http://dx.doi.org/10.1016/S0308-8146(01)00214-X

Takeiti, C. Y., Antonio, G. C., Motta, E. M., Collares-Queiroz, F. P., \& Park, K. J. (2009). Nutritive evaluation of a nonconventional leafy vegetable (Pereskia aculeata Miller). International Journal of Food Sciences and Nutrition, 60(Suppl. 1), 148160. PMid:19468927. http://dx.doi.org/10.1080/09637480802534509

Xu, X., Yu, L., \& Chen, G. (2006). Determination of flavonoids in Portulaca oleracea L. by capillary electrophoresis with electrochemical detection. Journal of Pharmaceutical and Biomedical Analysis, 41(2), 493-499. PMid:16516429. http://dx.doi.org/10.1016/j.jpba.2006.01.013

Yadav, S. K., \& Sehgal, S. (2002). Effect of domestic processing and cooking methods on total, $\mathrm{HCl}$ extractable iron and in vitro availability of iron in spinach and amaranth leaves. Nutrition and Health, 16(2), 113-120. PMid:12102364.

http://dx.doi.org/10.1177/026010600201600205

Funding: Fundação de Amparo à Pesquisa do Estado de São Paulo/FAPESP [grant number 2017/05009-7 and grant number 2018/06332-9] and Coordenação de Aperfeiçoamento de Pessoal de Nível Superior/CAPES. 